\title{
Microfinance And Poverty Reduction: Some International Evidence
}

\author{
Sadegh Bakhtiari, (Bakhtiari_Sadegh@yahoo.com), Isfahan University, Iran
}

\begin{abstract}
Year 2005 was called international year of microcredit by United Nations. Since, micro finance has proven to be an effective tool for poverty reduction this paper argues that microfinance can be considered an important element for an effective poverty reduction strategy. It shows that access and efficient provision of microcredit can enable the poor to smooth their consumption, better manage their risks better, gradually build their assets, develop their micro enterprises, enhance their income earning capacity, and enjoy an improved quality of life. Microfinance services can also contribute to the improvement of resource allocation, promotion of markets, and adoption of better technology; thus, microfinance helps to promote economic growth and development. Also the characteristics of financial systems in developing counties will be discussed and argued that formal financial sector is not consistent with the needs and requirements of the poor and the existence of informal financial sector is a response to the shortcomings of the formal financial sector.
\end{abstract}

\section{INTRODUCTION}

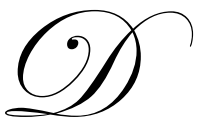

espite changes in development paradigms in the last half of the 20th century, the promise to bring wellbeing to all human being remained unfulfilled. As it stands more than 1.2 billion people in the world are struggling to survive. Even a country like US which has experienced a long and steady boom has not been able to benefit the life of its every citizen.

In 2005 , of the over 2.8 billion workers in the world, nearly 1.4 billion still did not earn enough to lift themselves and their families above the US $\$ 2$ a day poverty line - just as many as ten yearsago. ${ }^{1}$

ILO's mandate for pursuing action against poverty is contained in the Philadelphia Decalartion of 1944 which states that "poverty constitutes a danger to prosperity everywhere". This work is now being reinforced in the context of the international commitment to achieve the Millennium Development Goals (MDGs).

The poorest, especially women, when receive credit, they become economic actors with power, they can improve not only their own lives but, in a widening circle of impact, the lives of their families, their communities, and their nations. For many people particularly in the rural areas of developing countries to create and run a tiny business micro enterprise - mainly in the unregulated informal sector microcredit is very important. In this matter microcredit means providing small working capital loans to the self-employed poor. Even small amounts of capital can make the difference between absolute poverty and a thriving little business generating enough income to feed the family, send kids to school, and build decent housing.

Evidence shows the positive impact of microfinance on poverty reduction as it relates to the first six out of seven Millennium Development Goals. ${ }^{2}$

\section{MICROFINANCE AND MICROCREDIT}

Microfinance is the provision of a broad range of financial services to low-income micro enterprises and households. The range of financial services usually includes savings, loans, insurance, leasing, money transfers, and others. 
Microcredit emphasizes the provision of credit services to low income clients, usually in the form of small loans for micro enterprise and income generating activities. Use of the term 'microcredit' is often associated with an inadequate amount of the value of savings for the poor. In most cases, the provision of savings services in 'microcredit' schemes simply involves the collection of compulsory deposit amounts that are designed only to collateralize those loans. Additional voluntary savings may collect but the clients have restricted access to their enforced savings. These savings become the main source of capital in the financial institutions.

\section{FINANCIAL INSTITUTIONS IN DEVELOPING COUNTRIES}

The financial systems of most developing countries are characterized by the existence and operation of two financial sectors alongside each other, namely the formal and informal financial sectors.

The formal financial sector, which consists of the central bank, commercial banks, development banks, saving banks, social security schemes, and insurance companies, is usually mainly active in the organized urbanoriented systems serving the monetized modern sector. On the other hand, the informal financial sector includes individuals such as moneylenders, relatives, friends, neighbors, landlords, traders, who deal with the traditional, rural, subsistence-oriented branch of the economy.

The existence of the informal financial sector may be a response to the shortcomings of the formal financial sector due to various restrictions imposed by governments on the activities of such institutions while the informal financial system characterized by a high degree of flexibility, ease of transactions and its emphasize on personal relationship. Also this dualism can be explained by the reality that both in the economic and social status of developing countries, a kind of dualism can be observed and the financial sector dualism is a product of this rather than a cause.

\section{ROLE OF MICROFINANCE IN POVERTY REDUCTION}

Microfinance is about providing financial services to the poor who are not served by the conventional formal financial institutions - it is about extending the frontiers of financial service provision. The provision of such financial services requires innovative delivery channels and methodologies.

The need for financial services that allow people to both take advantage of opportunities and better management of their resources. Microfinance can be one effective tool amongst many for poverty alleviation. However, it should be used with caution -despite recent claims, the equation between microfinance and poverty alleviation is not straight-forward, because poverty is a complex phenomenon and many constraints that the poor in general have to cope with. We need to understand when and in what form microfinance is appropriate for the poorest; the delivery channel, methodology and products offered are all inter-linked and in turn affect the prospect and promise of poverty alleviation.

Access to formal banking services is difficult for the poor. The main problem the poor have to take when trying to acquire loans from formal financial institutions is the demand for collateral asked by these institutions. In addition, the process of acquiring a loan entails many bureaucratic procedures, which lead to extra transaction costs for the poor. Formal financial institutions are not motivated to lend money to them. In general, formal financial institutions show a preference for urban over rural sectors, large-scale over small scale transactions, and nonagricultural over agricultural loans. Formal financial institutions have little incentives to lend to the rural poor for the following reasons.

- Administral difficulties: small rural farmers often live geographically scattered in areas with poor communication facilities, making loan administration difficult.

- $\square$ Systematic risks: agricultural production is associated with some systemic risks, such as drought and floods, which is reflected in a high covariance of local incomes.

- $\square$ Lack of information: the absence of standardized information, standard lending tools, such as financial statements or credit histories, does not exist in these areas. 
- $\square$ Repayment problems: the repayment of working capital may be required only once a year for example during the harvest season.

On the other hand, access to informal loans is relatively easy, convenient, and available locally to low income households for the following reasons.

- $\square$ Informal moneylenders use interlinked credit contracts to reduce default risk such as development of business relationship with the clients.

- $\square$ Informal moneylenders have local information which helps them to appraise credit needs and credit worthiness of the client.

- $\square$ Informal moneylenders are considering the needs and requirements of clients even for small amount of loan.

- $\square$ Informal moneylenders will profit from social sanctions such as those that may exist between members of a family. These sanctions may serve as a substitute for legal enforcement.

- $\square$ Informal moneylenders use specific incentives to stimulate repayment, such as repeat lending to borrowers who repay promptly, with gradually increasing loan size.

Despite the fact that many rural poor acquire their loans from the informal financial sector in rural areas of developing countries; the sector has some basic limitations. A common feature of many rural communities is that much of the local information does not flow freely; it tends to be segmented and circulates only within specific groups. Usually the informal credit market is based on local economies and is thus limited by local wealth constraints and the covariant risks of the local environment.

Since most of the world's poor do not have access to basic financial services that would help them manage their assets and generate income. To overcome poverty, they need to be able to borrow, save, and invest, and to protect their families against adversity.

Another shortcoming of the two financial sectors in developing countries is their inability to satisfy the credit needs of the poor has led to the new development of microfinance. Microfinance is believed to be able to reduce the above-mentioned inadequacies of formal and informal financial institutions and is emerging as an important credit partner to the poor in the developing world.

\section{GRAMEEN BANK IN BANGLADESH (THE NEW HISTORY OF MICROCREDIT)}

The new history of Microcredit goes back to the 1970s when professor Muhamad Yunus started the Grameen bank project in Bangladesh in response to a devastating famine in 1974. His aim was to provide financial services, mainly loans and advise to the poor. He found that the poor needed finance for livestock-raising, trading, production in cottage industries, and services. Those who repaid promptly were able to acquire bigger loans and reap profits in different ventures.

In fact the poor all over the world are trapped in a kind of exploitation. While they work extremely hard and create enormous wealth, the middle-men, money-lenders, and employers keep the fruits of their labor. The poor have no access to "institutional credit", because they can not provide collateral. The system keeps them firmly trapped in debt, poverty, and exploitation. Grameen always considers and guards the basic following principles

- $\quad$ The bank would lend only to the poorest of the poor in the rural areas.

- $\quad$ The bank would remain women-focused. $94 \%$ of its customers are women.

- These loans would be without collateral or security.

- $\quad$ The borrower - and not the bank - would decide the business activity the loan will be utilized for.

- $\quad$ The bank would help and support the borrower in succeeding.

- $\quad$ Borrowers will pay as little or as much interest as required to keep the bank self reliant (that is, not dependent on grants or donations). 
According to Muhammad Yunus, the founder of Grameen Bank, development should mean the development of the bottom $50 \%$ of population, especially bottom $50 \%$ of those who live below the poverty line. A poor person, like anyone else, has a potential for growth. Given the access to credit, the poor can build the future and overcome poverty. The experiences of Grameen Bank in Bangladesh as well as other similar bank in different countries can be taken into consideration to see how this happens.

To see the microfinance institutions and the impact of micro credit on poverty reduction in different parts of the world, we discuss below some other experiences in this matter.

\section{BANK RAKYAT IN INDONESIA (BRI)}

Bank Rakyat Indonesia (BRI) is a government commercial bank that began as an agricultural development bank. At present time, BRI services are offered in Indonesia through an independent microfinance unit to both rural and urban clients.

The case of Rakyat Bank, is evidence that, in a deregulated policy environment, the microcredit operations of an ailing government-owned agricultural development bank can be transformed into a highly profitable, self-reliant microfinance intermediary. Since 1984, BRI has evolved into a major microfinance provider. Massive staff retraining in the new microbanking culture, with its new financial services and incentive schemes, was of crucial importance. Its 3,700 local units serve some 29.8 million savings accounts and 3.1 million borrowers (Dec 2001). With non-targeted loans of from $\$ 5$ to $\$ 5000$ at rural market rates of interest and unrestricted deposit services, it reaches out to vast number of the poor and the non-poor. Making good use of a start-up liquidity injection, it has fully replaced external funds with local savings since 1989.

The ultimate test came with the Asian financial crisis. When the Indonesian banking system collapsed, BRI's Microbanking Division remained profitable. At the peak of the crisis, from June to August 1998, the local units attracted 1.29 million new savers during the three-month period.

\begin{tabular}{|l|c|c|}
\hline As of December 2001 & Microloans & Microsavings \\
\hline Number of active clients & $3,100,358$ & $29,869,197$ \\
\hline Microaccount portfolio value (\$US) & $\$ 1,710,576,471$ & $\$ 3,226,964,706$ \\
\hline Minimum amount & $\$ 5$ & N/A \\
\hline Maximum amount & $\$ 6,000$ & $38 \%$ \\
\hline Microfinance as a percentage of total portfolio & $31 \%$ & $90 \%$ \\
\hline Percentage of microaccounts with < \$500US & $90 \%$ & \\
\hline
\end{tabular}

Note: IDR/USD $=8,500$. Source: www.swwb.org/english/1000/address/geni/ad_genbi_rakyat.htm

\section{THAILAND'S BAAC ${ }^{3}$}

The Thailand Bank for Agriculture and Agricultural Cooperatives' (BAAC) reform has been guided by two, sometimes conflicting, objectives: outreach to all farm households as its political mandate; and financial viability in the bank's own interest. Important elements in the reform process have been:

- A corporate culture emphasizing cost-effectiveness, productivity, and efficiency.

- $\quad$ Decentralization and expansion of branch network operating as profit centers.

- Individual lending through joint liability groups, as a financial technology attuned to Thai culture.

- Substantial improvements in portfolio quality, which created depositor confidence.

- A radical shift in the financial resource base to rural savings mobilization. 
BAAC has demonstrated how gradual reform can be carried through in periods of financial repression, with directed credit, interest rate ceilings, and mandated agricultural lending quotas. Under these restrictions, BAAC expanded its outreach, forced cost-efficiency upon its staff, and prepared the ground for deposit mobilization.

\section{INDIA'S SHARE}

Society for Helping Awakening Rural Poor through Education (SHARE) has grown into a major microfinance institution in India that provides financial services to more than 61,000 poorest women in the rural areas of Andhra Pradesh. It started its operation in 1992. It has different loan products including loan for housing. More than $50 \%$ of its loans have gone for animal husbandry projects. Up to September 2000, SHARE has disbursed over \$ 13 million to its borrowers and mobilized an amount of more than \$1.3 million as savings. It is enjoying $100 \%$ repayment of its loans. According to Latifee(2000), $85 \%$ of SHARE clients constitute the bottom $20 \%$ of the individuals living below poverty line. A recent impact study on women who have been borrowing from SHARE showed very positive results of SHARE operation on the life of its borrowers in terms of increase in income, improved nutrition, increased expenditure on non-food basic needs, shift from wage employment to self-employment, increased access to agricultural land, increase in savings, better housing, women empowerment, etc. The study indicates that about 50\% of the SHARE households have already crossed the poverty line. SHARE has already achieved operating self-sufficiency. It hopes to achieve financial self sufficiency very soon.

\section{PHILIPPINES' CARD ${ }^{5}$}

Center for Agriculture and Rural Development (CA RD) is one of the leading microfinance institutions in the Philippines. It is serving more than 34,000 poorest women. By the end of September 2000, it has disbursed about $\$ 17.25$ million to its borrowers as loans and mobilized over $1 \$ .4$ million as savings from them. Its repayment rate is $100 \%$. It has already achieved institutional viability. According to an evaluation study, CARD has largely succeeded in reaching very low income households and generating the self-employment and significantly increasing their income. At the time of joining $100 \%$ of CARD members belonged to the bottom $50 \%$ of the population living under poverty line. As per CARD impact study $50 \%$ of its borrowers have already crossed the poverty line.

\section{CONCLUDING REMARKS}

Microcredit and microfinance have received extensive recognition as a strategy for poverty reduction and for economic empowerment. Microfinance is a way for fighting poverty, particularly in rural areas, where most of the world's poorest people live. Accessing small amounts of credit at reasonable interest rates give poor people an opportunity to set up their own small business. Many studies show that poor people are trustable, with higher repayment rates than conventional borrowers.

When poor people have access to financial services, they can earn more, build their assets, and cushion themselves against external shocks. Poor households use microfinance to move from everyday survival to planning for the future: they invest in better nutrition, housing, health, and education.

Most poor people cannot get good financial services that meet their needs because there are not enough strong institutions that provide such services. Strong institutions need to charge enough to cover their costs. Cost recovery is not an end in itself. Rather, it is the only way to reach scale and impact beyond the limited levels that donors can fund. A financially sustainable institution can continue and expand its services over the long term. Achieving sustainability means lowering transaction costs, offering services that are more useful to the clients, and finding new ways to provide banking services to the poor. At the end it should be mentioned that Poor people with no income or means of repayment need other kinds of support before they can make good use of loans. In many cases, other tools will alleviate poverty better-for instance, small grants, employment and training programs, or infrastructure improvements. Where possible, such services should be coupled with building savings. 


\section{REFERENCES}

1. Dunford, Christopher. 2001. Building Better Lives: Sustainable Linkage of Microfinance and Education in Health, Family Planning, and HIV/AIDS Prevention for the Poorest Entrepreneurs. http://www.microcreditsummit.org/papers/papers.htm.

2. Dunford, Christopher and Vicki Denman. November 2000. The Case for Credit With Education: A Promising Title II Microfinance Strategy for Cost Effective and sustainable Impact on Chronic Food Insecurity and Malnutrition. Freedom from Hunger. www.fantaproject.org/downloads/pdfs/cwe.pdf.

3. Gibbons, David S. 1999. International Replication of Grameen Banking: What Can the Poultry Network Learn from It? Proceedings of a Workshop - Poultry as a Tool in Poverty Eradication and Promotion of Gender Equality. http://www.husdyr.kvl.dk/htm/php/tune99/6-Gibbons.htm.

4. Garson, Jose. Microfinance and Anti-Poverty Strategies. A Donor Perspective. UNCDF. http://www.undp.org/uncdf/pubs/mf/mf-chap1.htm\#a.

5. ILO (2006), Global Employment Trends, Brief, Geneva, International Labour Office, January, PP.1-12. www.ilo.org/public/english/ employment/strat/download/getb06en.pdf.

6. International Labour Organization. Women in the informal sector and their access to microfinance. http://www.ilo.org/public/english/employment/ent/papers/women.htm.

7. Latifee, H. I. 2000, Microfinance and Poverty Reduction: Experiences of Grameen Operation in Asia, BRAC Center for Development Management (BCDM), Rajendrapur, Bangladesh.

8. Lustiq, Nora and Omar Arias. Poverty Reduction, Finance, and Development, Quarterly Journal of the IMF . 37 (1).

9. Marcus, Rachel, Beth Porter, and Caroline Harper. 1999. Money Matters: Understanding Microfinance. Save the Children. London.

10. Oxfam GB Policy Department for UNICEF. August 1999. From Unsustainable Debt to Poverty Reduction: Reforming the Heavily Indebted Poor Countries Initiative. http://www.oxfam.org.uk/policy/papers/hipcref/hipcref.htm.

11. Pitt, Mark M. and Shahidur R. Khandker. 1996. Household and Intrahousehold Impact of the Grameen Bank and Similar Targeted Credit Programs in Bangladesh. World Bank Discussion Papers 320. Washington, DC.

12. Rahman, Aminur. 1999. Micro-credit Initiatives for Equitable and Sustainable Development: Who Pays? World Development. 27 (1) p. 67-82.

13. Rodriguez-Meza. 2000. Microcredit and the Poorest of the Poor: Theory and Evidence From Bolivia. World Development. 28 (2) http://www.microfinance.com/English/Papers/Bolivia_Poorest.pdf.

14. Seibel, Hans Dieter and Dolores Torres. 1999. Are Grameen Replications Sustainable, and Do They Reach the Poor? The Case of CARD Rural Bank in the Philippines. Journal of Microfinance. 1 (1).

15. World Bank. Poverty Reduction in Fiscal 1998. Strategy and Implementation http://www.worldbank.org/poverty/library/progr/.

16. Zaman, Hassan. 2000. Assessing the Poverty and Vulnerability Impact of Micro-Credit in Bangladesh: A case study of BRAC. World Bank. www.worldbank.org/html/dec/Publications/Workpapers/wps2000series/wps2145/wps2145.pdf.

\section{ENDNOTES}

1. $\quad \operatorname{ILO}(2006), \mathrm{p}$.

2. Millennium Goals are: (1) reduce the proportion of people living in extreme poverty by half between 1990 and 2015 (defined as people living on less than $\$ 1$ a day), (2) enroll all children in primary school by 2015, (3) make progress towards gender equality and empowering women by eliminating gender disparities in primary and secondary education by 2005, (4) reduce infant and child mortality rates by two-thirds between 1990 and 2015, (5) reduce maternal mortality ratios by three-quarters between 1990 and 2015, provide access for all who need reproductive health services by 2015 , and -Implement national strategies for sustainable development by 2005 so as to reverse the loss of environmental resources by 2015.

3. Zaman, Hassan.( 2000).

4. Latifee H. I. (2000).

5. Latifee H. I. (2000). 
1. ILO (2006), p.

${ }^{2}$. Millennium Goals are: (1) reduce the proportion of people living in extreme poverty by half between 1990 and 2015 (defined as people living on less than \$1a day), (2) enroll all children in primary school by 2015 , (3) make progress towards gender equality and empowering women by eliminating gender disparities in primary and secondary education by 2005, (4) reduce infant and child mortality rates by two-thirds between 1990 and 2015, (5) reduce maternal mortality ratios by three-quarters between 1990 and 2015 , provide access for all who need reproductive health services by 2015 , and -Implement national strategies for sustainable development by 2005 so as to reverse the loss of environmental resources by 2015.

3 . Zaman, Hassan.( 2000).

4 . Latifee H. I. (2000)

5 . Latifee H. I. (2000) 